\title{
Flavobacterium glycines sp. nov., a facultative methylotroph isolated from the rhizosphere of soybean
}

\author{
Munusamy Madhaiyan, ${ }^{1,2}$ Selvaraj Poonguzhali, ${ }^{1}$ Jung-Sook Lee, ${ }^{3}$ \\ Keun Chul Lee ${ }^{3}$ and Subbiah Sundaram ${ }^{1}$ \\ ${ }^{1}$ Department of Agricultural Microbiology, Tamilnadu Agricultural University, Coimbatore 641003 , \\ Tamilnadu, India \\ ${ }^{2}$ Temasek Life Sciences Laboratory, 1 Research Link, National University of Singapore, Singapore \\ 117604 \\ ${ }^{3}$ Korean Collection for Type Cultures (KCTC), Biological Resource Center (BRC), \\ Korea Research Institute of Bioscience and Biotechnology (KRIBB), 111 Gwahangno, Yusong-gu, \\ Daejeon 305-806, Republic of Korea
}

Correspondence

Munusamy Madhaiyan mmadhaiyan@hotmail.com
The genus Flavobacterium, first proposed by Bergey et al. (1923) and the description of which was emended considerably by Bernardet et al. (1996), is the type genus of the family Flavobacteriaceae in the phylum Bacteroidetes (formerly the Cytophaga-Flavobacterium-Bacteroides group) (Ludwig et al., 2008). Flavobacterium species have been isolated from polar environments, seawater, fresh water and river sediment, but relatively few have been isolated from soil environments (Kirchman, 2002; Kim et al., 2006; Yoon et al., 2006). Twenty-six recognized species of Flavobacterium were listed by Bernardet \& Bowman (2006), but many novel species have since been described (http://www.bacterio. cict.fr/f/flavobacterium.html). Methylotrophic bacteria can turn over one-carbon $\left(\mathrm{C}_{1}\right)$ compounds in the

Abbreviations: ACC, 1-aminocyclopropane-1-carboxylate; ACCD, ACC deaminase; IAA, indole-3-acetic acid.

The GenBank/EMBL/DDBJ accession numbers for the 16S rRNA and $m \times a F$ gene sequences of strain $\mathrm{Gm}-149^{\top}$ are EU672803 and EU912490, respectively.

A supplementary figure showing a scanning electron micrograph of cells of strain $\mathrm{Gm}-149^{\mathrm{T}}$ is available with the online version of this paper. environment. They represent a diverse group of organisms that have many potential practical applications due to their unique metabolic capacities. Methylotrophy is widespread in the bacterial world and is found within members of the phyla Alphaproteobacteria, Betaproteobacteria, Gammaproteobacteria and Firmicutes (Lidstrom, 2006). Facultative methylotrophy has been reported in Flavobacterium strains isolated from sediment of the River Thames (London, UK), but the strains were not characterized fully (Boden et al., 2008). Recent studies in our laboratory focusing on the methylotrophic bacterial population associated with different agriculturally important crops, such as rice, red pepper and soybean collected from various locations, have yielded a large number of isolates. In the present study, one novel isolate, designated strain $\mathrm{Gm}-149^{\mathrm{T}}$, with an ability to produce 1-aminocyclopropane1-carboxylate deaminase (ACCD) was investigated. Based on the data presented here, this strain is shown to represent a novel species of the genus Flavobacterium.

Strain $\mathrm{Gm}-149^{\mathrm{T}}$ was isolated from rhizosphere soil of soybean (Glycine $\max$ L. cv. CO1) collected from an 
experimental plot at the Tamilnadu Agricultural University, Coimbatore, India. Selective ammonium mineral salts (AMS) medium (Whittenbury et al., 1970) supplemented with filter-sterilized cycloheximide $\left(10 \mu \mathrm{g} \mathrm{ml}^{-1}\right)$ and methanol $(0.5 \%, \mathrm{v} / \mathrm{v})$ was used for isolation at $28{ }^{\circ} \mathrm{C}$ by the serial-dilution technique. Strain $\mathrm{Gm}-149^{\mathrm{T}}$ was able to grow slowly on AMS or R2A agars. It was cultured routinely on the same medium at $30{ }^{\circ} \mathrm{C}$ and preserved as a suspension in R2A broth with $50 \%$ glycerol at $-80{ }^{\circ} \mathrm{C}$. Flavobacterium daejeonense KACC $11422^{\mathrm{T}}$, Flavobacterium johnsoniae DSM $2064^{\mathrm{T}}$, Flavobacterium defluvii DSM $17963^{\mathrm{T}}$ and Flavobacterium soli DSM $19725^{\mathrm{T}}$ were grown under the same conditions and were studied in parallel with the new isolate by using the same phenotypic tests. Phenotypic properties were studied according to standard procedures (Gerhardt et al., 1994). Biolog GN2 microplates were used to assess utilization of carbon compounds; utilization of carbon compounds not included with the GN2 plates was assessed by using the methods described by Madhaiyan et al. (2007a) and Green \& Bousfield (1982). Other physiological and biochemical characteristics were tested by using the API ZYM and API 20NE galleries (bioMérieux) following the manufacturer's instructions. Scanning electron microscope observations were performed as described by Bozzola \& Russell (1998) by using a Hitachi S-2500C microscope with GEMINI column equipped with a field-emission electron source. Gliding motility and absorption of Congo red by the colonies were determined by using the methods of Bernardet et al. (2002). Flexirubin-type pigments were detected by flooding the plates with $20 \%(\mathrm{w} / \mathrm{v})$ potassium hydroxide (Fautz \& Reichenbach, 1980). Pigments were extracted by methanol from a 5-day-old R2A broth culture. The resultant supernatant was scanned for absorbance at a wavelength of $190-1100 \mathrm{~nm}$ at room temperature on a UV-1601 spectrophotometer (Shimadzu). The minimal inhibitory concentrations of heavy metals and antibiotics were determined as described by Madhaiyan et al. (2007b) and Chanprame et al. (1996). A quantitative assay for indole-3acetic acid (IAA) and plate assays for detecting the presence of siderophore production, ACCD activity, acetylene reduction and sulfur oxidation were carried out as described by Poonguzhali et al. (2006). Quantitative estimation of methanol dehydrogenase activity was carried out according to the procedure of Dunfield et al. (2003).

Phenotypic features of strain $\mathrm{Gm}-149^{\mathrm{T}}$ are given in Table 1 and in the species description below. Some of these characteristics were in accordance with those of members of the genus Flavobacterium, whereas others allowed the differentiation of strain $\mathrm{Gm}-149^{\mathrm{T}}$ from closely related Flavobacterium species (Table 1). Flexirubin-type pigments were produced, as shown by the colour shift of the colonies when flooded with $20 \% \mathrm{KOH}$. Carotenoid pigments were also produced, as revealed by absorption maxima at 213 , 261, 449 and $476 \mathrm{~nm}$ of the methanol extract (Asker et al., 2007). Strain $\mathrm{Gm}-149^{\mathrm{T}}$ was able to utilize 1-aminocyclopropane-1-carboxylate (ACC) as a nitrogen source when tested by plate assay, and considerable activity of ACCD was detected in cell-free extracts. F. daejeonense KACC $11422^{\mathrm{T}}$, F. johnsoniae DSM $2064^{\mathrm{T}}$, F. defluvii DSM $17963^{\mathrm{T}}$ and F. soli DSM $19725^{\mathrm{T}}$ were tested under the same conditions by preliminary plate assay on AMS supplemented with $30 \mu \mathrm{mol}$ ACC as a nitrogen source. These four strains were negative for ACCD activity. Strain Gm-149 ${ }^{\mathrm{T}}$ showed no activity for sulfur oxidation and was negative in the siderophore assay, but was positive for nitrogenase activity $\left[4.4 \mathrm{nmol} \mathrm{C}_{2} \mathrm{H}_{4}(\mathrm{mg} \text { protein })^{-1} \mathrm{~h}^{-1}\right.$ ], IAA production $\left(1.8 \mu \mathrm{g} \mathrm{ml}^{-1}\right)$ and ACCD activity [18.5 nmol $\alpha$ ketobutyrate (mg protein $)^{-1} \mathrm{~h}^{-1}$ ]. Strain $\mathrm{Gm}-149^{\mathrm{T}}$ produced methanol dehydrogenase at a concentration of $8.4 \mathrm{nmol} \mathrm{m^{-1 }}$ (mg protein $)^{-1}$. Seed inoculation with strain $\mathrm{Gm}-149^{\mathrm{T}}$ significantly increased the root length of canola (Brassica campestris L.; $22.4 \%$ increase versus control) and tomato (Lycopersicon esculentum Mill.; $26.3 \%$ increase versus control) (data not shown).

Chromosomal DNA was extracted by using a QIAamp DNA mini kit (Qiagen). The 16S rRNA gene was amplified by using the universal primers $27 \mathrm{~F}$ and $1492 \mathrm{R}$ as described by Madhaiyan et al. (2009) and the full gene sequence was determined by the fluorescent dye-terminator method by using a sequencing kit (ABI PRISM Big Dye terminator cycle sequencing ready reaction kit version 3.1). The amplified

Table 1. Differential characteristics between strain $\mathrm{Gm}-149^{\top}$ and the type strains of related Flavobacterium species

Strains: $1, \mathrm{Gm}-149^{\mathrm{T}} ; 2$, F. daejeonense KACC $11422^{\mathrm{T}} ; 3$, F. defluvii DSM $17963^{\mathrm{T}}$; 4, F. johnsoniae DSM $2064^{\mathrm{T}}$; 5, F. soli DSM $19725^{\mathrm{T}}$. All are positive for catalase activity and growth on nutrient and trypticase soy agars at $25{ }^{\circ} \mathrm{C}$. All are negative for urease activity and precipitation on egg-yolk agar. + , Positive; - , negative; w, weakly positive. All data are from the present study.

\begin{tabular}{|lccccc|}
\hline Characteristic & $\mathbf{1}$ & $\mathbf{2}$ & $\mathbf{3}$ & $\mathbf{4}$ & $\mathbf{5}$ \\
\hline Flexirubin-type pigment & + & - & + & + & - \\
Gliding motility & + & - & + & + & - \\
Highest NaCl concentration & 1 & 3 & $<2$ & 1 & 2 \\
$\quad$ \%) tolerated & & & & & \\
Acid from carbohydrate & + & + & + & + & - \\
Glucose utilization & - & + & + & + & + \\
Oxidase & W & + & - & + & + \\
Degradation of: & & & & & \\
Gelatin & - & - & + & + & + \\
Casein & + & - & + & + & - \\
Starch & + & + & - & + & - \\
CM-cellulose & - & - & + & + & - \\
Pectin & - & - & - & + & W \\
Chitin & - & - & - & + & W \\
Aesculin & - & + & + & + & + \\
$\quad$ Tyrosine & - & - & + & + & - \\
$\beta$-Galactosidase activity & + & + & W & + & - \\
Nitrate reduction & + & + & - & + & - \\
DNA G+C content (mol\%) & 35.6 & 35.0 & 33.5 & 34.0 & 36.9 \\
& & & & & \\
\hline
\end{tabular}


products were analysed on an ABI PRISM 310 Genetic Analyzer (Applied Biosystems). The resultant 16S rRNA gene sequence was compared with those of the type strains of representative species of the genus Flavobacterium and related genera retrieved from GenBank, and the sequences were aligned by using CLUSTAL W (Thompson et al., 1994). Phylogenetic relationships were determined with the neighbour-joining (Saitou \& Nei, 1987), maximum-parsimony (Fitch, 1971) and maximum-likelihood (Felsenstein, 1981) methods by using the program MEGA4.1 (Tamura et al., 2007), with bootstrap values based on 1000 replications (Felsenstein, 1985). Sequence similarity values were computed by using two tools: the FASTA nucleotide similarity search program (Pearson \& Lipman, 1988) and the EzTaxon Server (Chun et al., 2007). The methanol dehydrogenase $(m \times a F)$ and ACCD $(a c d S)$ genes were amplified from DNA extracted from strain $\mathrm{Gm}-149^{\mathrm{T}}$ and the four reference strains by using the primer pairs $\mathrm{mxaF}$
f1003/mxaF r1561 and F1936/F1939, respectively (McDonald \& Murrell, 1997; Blaha et al., 2006). The presence of the nifH gene was assessed by PCR amplification of a $390 \mathrm{bp}$ fragment of this gene by using the specific primers 19F and 407R (Ueda et al., 1995). The products were sequenced directly and analysed as described above.

The neighbour-joining phylogenetic tree with selected $16 \mathrm{~S}$ rRNA gene sequences showed that strain $\mathrm{Gm}-149^{\mathrm{T}}$ was related to members of the genus Flavobacterium (Fig. 1). $16 S$ rRNA gene sequence similarity calculations and phylogenetic analysis revealed that strain $\mathrm{Gm}-149^{\mathrm{T}}$ was related most closely to $F$. daejeonense KACC $11422^{\mathrm{T}}$ (97.1\%), F. johnsoniae DSM $2064^{\mathrm{T}}$ (96.9\%) and F. defluvii DSM $17963^{\mathrm{T}}(96.9 \%)$. Pairwise $16 \mathrm{~S}$ rRNA gene sequence comparisons via FASTA nucleotide similarity searches and the EzTaxon Server showed that strain $\mathrm{Gm}-149^{\mathrm{T}}$ was related most closely to $F$. daejeonense KACC $11422^{\mathrm{T}}$. The

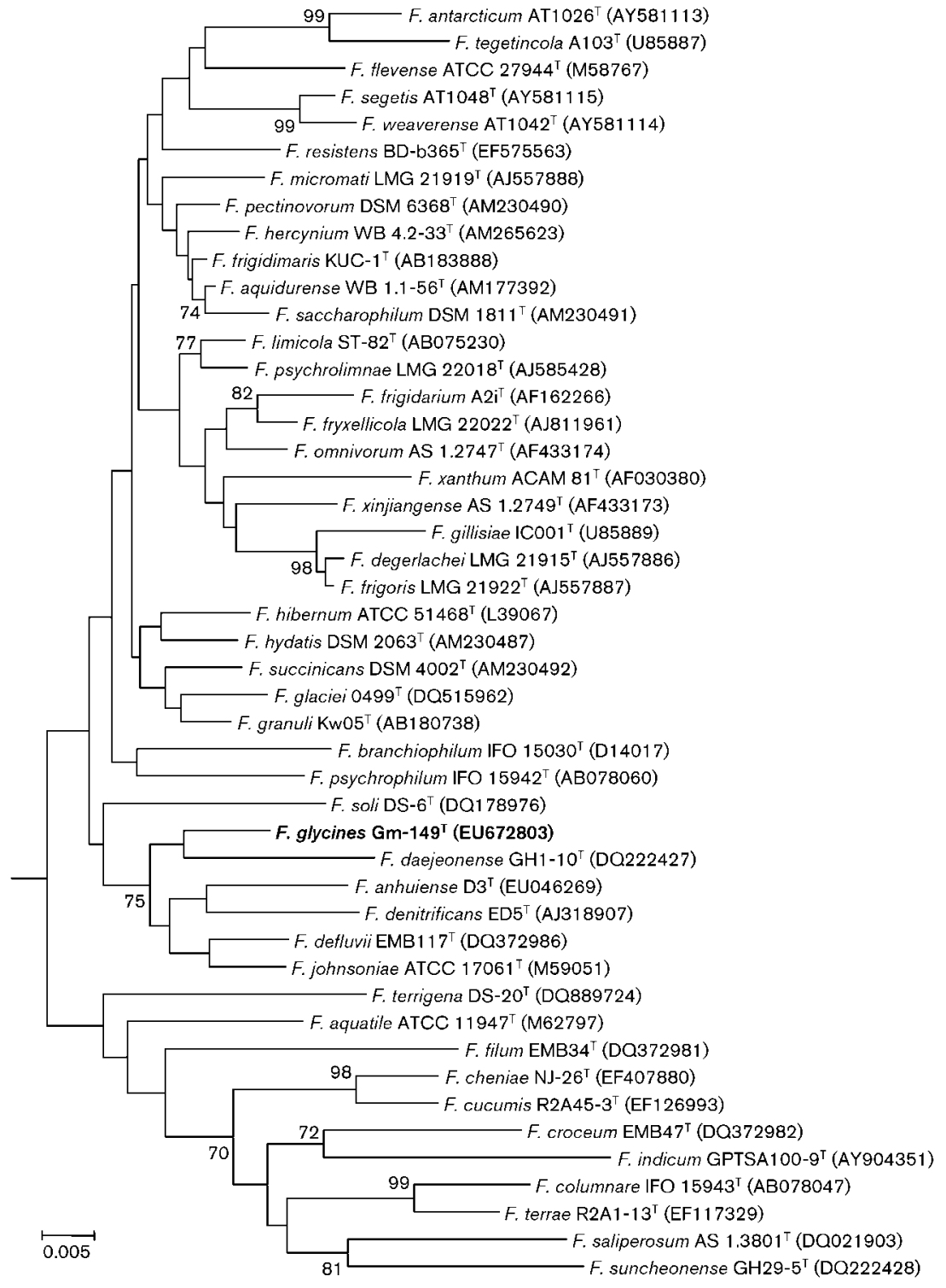

Fig. 1. Phylogenetic tree based on $16 \mathrm{~S}$ rRNA gene sequence comparison showing the position of strain $\mathrm{Gm}-149^{\top}$ among Flavobacterium species. Numbers at nodes indicate levels of bootstrap support based on a neighbour-joining analysis of 1000 resampled datasets; only values $\geqslant 70 \%$ are shown. Bar, 0.005 substitutions per nucleotide position. 
topologies of the trees generated with the neighbourjoining, maximum-parsimony and maximum-likelihood methods were almost identical (data not shown). An amplification product of the expected size for the mxaF gene $\left(572 \mathrm{bp}\right.$ ) was detected in strain $\mathrm{Gm}-149^{\mathrm{T}}$ and was similar to the mxaF genes of Methylobacterium species. Sequencing of the $m x a F$ gene of strain $\mathrm{Gm}-149^{\mathrm{T}}$ revealed $97.2 \%$ sequence similarity to that of the type strain of Methylophilus methylotrophus. The mxaF gene could not be amplified from the four reference Flavobacterium strains. The acdS gene was not detected in strain $\mathrm{Gm}-149^{\mathrm{T}}$ or the four reference Flavobacterium strains. The nifH gene was detected in all five strains (data not shown).

For analysis of cellular fatty acids, strain $\mathrm{Gm}-149^{\mathrm{T}}$ and the four reference strains were grown on TSA at $28{ }^{\circ} \mathrm{C}$ for $48 \mathrm{~h}$. Fatty acids were extracted, esterified, analysed by GC (Hewlett Packard 6890) and identified by using the Microbial Identification System (MIDI; Microbial ID) software package, according to standard protocols (Sasser, 1990). The G +C content of the genomic DNA of strain $\mathrm{Gm}-149^{\mathrm{T}}$ was determined by HPLC as described by Mesbah et al. (1989) by using a Supelcosil LC-18-S reversed-phase column (Supelco). DNA-DNA hybridization experiments between strain $\mathrm{Gm}-149^{\mathrm{T}}$ and the four reference strains were carried out on a nitrocellulose membrane according to the method of Seldin \& Dubnau (1985). The DIG-High prime system and the DIG luminescent detection kit (Roche Diagnostics $\mathrm{GmbH}$ ) were used to label the DNA probe and for visualization. Hybridization temperatures were 60 and $65{ }^{\circ} \mathrm{C}$ and the level of DNA-DNA relatedness was quantified by using a densitometer (Bio-Rad Laboratories). Respiratory quinones were extracted and analysed according to Kroppenstedt (1982).

The major fatty acids $(>9 \%)$ of strain $\mathrm{Gm}-149^{\mathrm{T}}$ were iso$\mathrm{C}_{15: 0}$, summed feature 3 (comprising iso- $\mathrm{C}_{15: 0} 2-\mathrm{OH}$ and/or $\left.\mathrm{C}_{16: 1} \omega 7 c\right), \mathrm{C}_{16: 0} 3-\mathrm{OH}$ and anteiso- $\mathrm{C}_{15: 0}$. This profile was similar to those of the type strains of its four closest phylogenetically related species, but there were clear differences in the respective proportions of some components between the five strains (Table 2). The DNA G $+\mathrm{C}$ content of strain $\mathrm{Gm}-149^{\mathrm{T}}$ was $35.6 \mathrm{~mol} \%$, a value within the range reported for the genus Flavobacterium (Bernardet \& Bowman, 2006). Strain $\mathrm{Gm}-149^{\mathrm{T}}$ showed a low level of DNA-DNA hybridization of 7.2-11.2\% with its four closest relatives, well below the $70 \%$ threshold generally accepted for species delineation (Stackebrandt et al., 2002). Therefore, on the basis of the data presented here, strain $\mathrm{Gm}-149^{\mathrm{T}}$ is considered to represent a novel species of the genus Flavobacterium, for which the name Flavobacterium glycines sp. nov. is proposed.

\section{Description of Flavobacterium glycines sp. nov.}

Flavobacterium glycines (gly.ci'nes. N.L. n. Glycine a botanical genus name; N.L. gen. n. glycines of Glycine max, from which the type strain was isolated).

Cells are Gram-staining-negative rods, $0.2-0.3 \mu \mathrm{m}$ in diameter and $0.8-1.0 \mu \mathrm{m}$ in length (see Supplementary
Table 2. Cellular fatty acid compositions of strain $\mathrm{Gm}-149^{\top}$ and of the type strains of related Flavobacterium species

Strains: $1, \mathrm{Gm}-149^{\mathrm{T}}$; 2, F. daejeonense KACC $11422^{\mathrm{T}}$; 3, F. defluvii DSM $17963^{\mathrm{T}}$; 4, F. johnsoniae DSM $2064^{\mathrm{T}}$; 5, F. soli DSM $19725^{\mathrm{T}}$. Values are percentages of total fatty acids. Fatty acids representing $<1 \%$ in all strains were omitted. All data are from the present study. tr, Trace $(<1 \%)$; ND, not detected.

\begin{tabular}{|c|c|c|c|c|c|}
\hline Fatty acid & 1 & 2 & 3 & 4 & 5 \\
\hline \multicolumn{6}{|l|}{ Saturated } \\
\hline $\mathrm{C}_{14: 0}$ & 3.0 & 1.0 & ND & ND & ND \\
\hline $\mathrm{C}_{15: 0}$ & ND & $\mathrm{ND}$ & 7.1 & 6.5 & 8.1 \\
\hline $\mathrm{C}_{16: 0}$ & 6.2 & 6.5 & 4.5 & 3.3 & 4.5 \\
\hline \multicolumn{6}{|l|}{ Hydroxy } \\
\hline $\mathrm{C}_{15: 0} 2-\mathrm{OH}$ & 1.3 & $\operatorname{tr}$ & $\operatorname{tr}$ & $\operatorname{tr}$ & ND \\
\hline $\mathrm{C}_{15: 0} 3-\mathrm{OH}$ & 2.8 & 2.6 & 2.2 & 2.1 & ND \\
\hline $\mathrm{C}_{16: 0} 3-\mathrm{OH}$ & 11.2 & 7.5 & 4.6 & 5.2 & 1.2 \\
\hline $\mathrm{C}_{17: 0} 3-\mathrm{OH}$ & 1.4 & 1.2 & 1.4 & 1.2 & $\mathrm{ND}$ \\
\hline \multicolumn{6}{|l|}{ Branched } \\
\hline iso- $\mathrm{C}_{14: 0}$ & 1.9 & $\operatorname{tr}$ & 1.2 & 1.2 & $\mathrm{ND}$ \\
\hline anteiso- $\mathrm{C}_{15: 0}$ & 9.2 & 5.2 & 4.3 & 4.1 & 4.6 \\
\hline iso- $\mathrm{C}_{15: 0}$ & 15.5 & 20.1 & 18.5 & 24.0 & 27.1 \\
\hline iso- $\mathrm{C}_{15: 1} \mathrm{G}$ & 3.3 & 5.1 & 6.5 & 5.4 & 5.1 \\
\hline iso- $\mathrm{C}_{15: 0} 3-\mathrm{OH}$ & 6.4 & 8.6 & 9.3 & 7.5 & 8.2 \\
\hline iso- $\mathrm{C}_{16: 0}$ & $\operatorname{tr}$ & $\operatorname{tr}$ & 2.9 & 3.2 & 3.3 \\
\hline iso- $\mathrm{C}_{16: 0} 3-\mathrm{OH}$ & 3.8 & 1.2 & 6.6 & 5.3 & 5.1 \\
\hline iso- $\mathrm{C}_{17: 0} 3-\mathrm{OH}$ & 4.5 & 9.4 & 12.9 & 10.5 & 7.1 \\
\hline iso- $\mathrm{C}_{17: 1} \omega 9 c$ & $\operatorname{tr}$ & ND & 2.6 & 2.7 & 7.4 \\
\hline \multicolumn{6}{|l|}{ Unsaturated } \\
\hline $\mathrm{C}_{15: 1} \omega 6 c$ & 5.9 & 6.0 & 1.3 & 1.3 & 1.9 \\
\hline $\mathrm{C}_{17: 1} \omega 6 c$ & 2.5 & 2.6 & 2.3 & 2.4 & 2.6 \\
\hline $\mathrm{C}_{17: 1} \omega 8 c$ & $\operatorname{tr}$ & $\operatorname{tr}$ & $\mathrm{ND}$ & ND & 1.3 \\
\hline \multicolumn{6}{|c|}{ Summed features ${ }^{*}$} \\
\hline 2 & 1.1 & 1.0 & 1.1 & 1.0 & $\mathrm{ND}$ \\
\hline 3 & 15.8 & 17.2 & 9.9 & 12.5 & 11.3 \\
\hline
\end{tabular}

${ }^{*}$ Summed features are groups of two or three fatty acids that could not be separated by GC with the MIDI system. Summed feature 2 comprised $\mathrm{C}_{12: 0}$ ALDE and/or unknown ECL 10.928; summed feature 3 comprised $\mathrm{C}_{16: 1} \omega 7 c$ and/or iso- $\mathrm{C}_{15: 0} 2-\mathrm{OH}$.

Fig. S1 in IJSEM Online), that are motile by gliding. Growth occurs at $10-35{ }^{\circ} \mathrm{C}$ (optimum, $28{ }^{\circ} \mathrm{C}$ ), at pH 6-8 and in the presence of $0-1 \% \mathrm{NaCl}$. Grows optimally on R2A medium without the addition of $\mathrm{NaCl}$; growth is severely inhibited on R2A medium containing $>1 \%(\mathrm{w} / \mathrm{v})$ $\mathrm{NaCl}$. Growth occurs on AMS, R2A, trypticase soy and nutrient agars, but not on MacConkey agar. Colonies are yellow, convex and circular with regular margins. Catalaseand oxidase-positive. Starch and casein are degraded, but gelatin, CM-cellulose, pectin, chitin, aesculin, tyrosine and egg yolk are not. Congo red is not absorbed by colonies. Flexirubin and carotenoid pigments are produced. Tolerates up to $2 \mathrm{mM} \mathrm{NiCl}_{2}$ and $0.5 \mathrm{mM} \mathrm{CdCl}_{2}$. Methanol, ethanol, succinate and dichloromethane are utilized as sole carbon sources, but methylamine, trimethylamine, diethanolamine, formaldehyde, dimethylamine and methane are not. Utilizes 
ammonium chloride, ACC, potassium nitrate, ammonium sulfate, sodium nitrate, L-glutamine, glycine and potassium thiocyanate as sole nitrogen sources, but not L-alanine, Lglutamate, urea, L-aspartate, L-tryptophan, methylamine, diethylamine, diphenylamine or potassium cyanate. Positive for nitrate reduction and $\beta$-galactosidase activity, but negative for glucose fermentation, arginine dihydrolase and urease activities, and aesculin and gelatin hydrolysis (API 20NE). In the same gallery, assimilates L-arabinose, Dmannose and maltose, but not D-glucose, D-mannitol, $\mathrm{N}$ acetylglucosamine, potassium gluconate, capric acid, adipic acid, malic acid, trisodium citrate or phenylacetic acid. In the API ZYM gallery, positive for alkaline phosphatase, esterase C4 (weak), esterase lipase C8 (weak), leucine arylamidase, valine arylamidase, acid phosphatase (weak), naphthol-AS-BI-phosphohydrolase, $\alpha$-galactosidase (weak) and $\beta$-galactosidase activities, but negative for lipase C14, cystine arylamidase, trypsin, $\alpha$-chymotrypsin, $\alpha$-glucosidase, $\beta$-glucosidase, $\beta$-glucuronidase, $\alpha$-mannosidase, $\alpha$-fucosidase and $N$-acetyl- $\beta$-glucosaminidase activities. The type strain is highly resistant (up to $500 \mu \mathrm{g} \mathrm{ml}^{-1}$ ) to spectinomycin, ampicillin, carbenicillin, nalidixic acid, bacitracin, cefotaxime, chloramphenicol, penicillin G, polymyxin B, novobiocin, vancomycin, doxycyclin, rifampicin, cephalosporin and trimethoprim, but sensitive to tetracycline $\left(500 \mu \mathrm{g} \mathrm{ml}^{-1}\right)$, gentamicin $\left(300 \mu \mathrm{g} \mathrm{ml}^{-1}\right)$, kanamycin $\left(300 \mu \mathrm{g} \mathrm{ml}^{-1}\right)$ and erythromycin $\left(500 \mu \mathrm{g} \mathrm{ml}^{-1}\right)$. The following substrates are utilized in the GN2 microplate system: $\alpha$-cyclodextrin, dextrin, glycogen, L-arabinose, cellobiose, Dfructose, L-fucose, D-galactose, $\alpha$-D-lactose, lactulose, maltose, D-mannose, melibiose, D-psicose, raffinose, L-rhamnose, sucrose, trehalose, turanose, pyruvic acid methyl ester, succinic acid monomethyl ester, D-galacturonic acid, Dglucuronic acid, $\alpha$-ketobutyric acid, DL-lactic acid and Lglutamic acid. All other substrates in the GN2 microplate system are not utilized. The major isoprenoid quinone is MK-6. The major cellular fatty acids are iso- $C_{15: 0}$, summed feature 3 (comprising iso- $\mathrm{C}_{15: 0} 2-\mathrm{OH}$ and/or $\mathrm{C}_{16: 1} \omega 7 \mathrm{c}$ ), $\mathrm{C}_{16: 0} 3-\mathrm{OH}$ and anteiso- $\mathrm{C}_{15: 0}$. The $\mathrm{G}+\mathrm{C}$ content of the genomic DNA of the type strain is $35.6 \mathrm{~mol} \%$.

The type strain, $\mathrm{Gm}-149^{\mathrm{T}}\left(=\mathrm{ICMP} 17618^{\mathrm{T}}=\mathrm{NBRC} 105008^{\mathrm{T}}\right)$, was isolated from the rhizosphere of field-grown soybean in Tamilnadu, India.

\section{Acknowledgements}

We thank Maureen Fletcher, ICMP, Auckland, New Zealand, and Yasuyoshi Nakagawa, NBRC, Chiba, Japan, for their valuable advice. We also thank Professor Jean P. Euzéby for his valuable advice on nomenclature. This work was financially supported by the Indian Council of Agricultural Research (ICAR), New Delhi, India.

\section{References}

Asker, D., Beppu, T. \& Ueda, K. (2007). Unique diversity of carotenoid-producing bacteria isolated from Misasa, a radioactive site in Japan. Appl Microbiol Biotechnol 77, 383-392.
Bergey, D. H., Harrison, F. C., Breed, R. S., Hammer, B. W. \& Huntoon, F. M. (editors) (1923). Bergey's Manual of Determinative Bacteriology. Baltimore, MD: Williams \& Wilkins.

Bernardet, J.-F. \& Bowman, J. P. (2006). The genus Flavobacterium. In The Prokaryotes, vol. 7, pp. 481-531. Edited by M. Dworkin, S. Falkow, E. Rosenberg, K.-H. Schleifer \& E. Stackebrandt. New York: Springer.

Bernardet, J.-F., Segers, P., Vancanneyt, M., Berthe, F., Kersters, K. \& Vandamme, P. (1996). Cutting a Gordian knot: emended classification and description of the genus Flavobacterium, emended description of the family Flavobacteriaceae, and proposal of Flavobacterium hydatis nom. nov. (basonym, Cytophaga aquatilis Strohl and Tait 1978). Int J Syst Bacteriol 46, 128-148.

Bernardet, J.-F., Nakagawa, Y. \& Holmes, B. (2002). Proposed minimal standards for describing new taxa of the family Flavobacteriaceae and emended description of the family. Int J Syst Evol Microbiol 52, 1049-1070.

Blaha, D., Prigent-Combaret, C., Sajjad Mirza, M. \& Moënne-Loccoz, Y. (2006). Phylogeny of the 1-aminocyclopropane-1-carboxylic acid deaminase-encoding gene acdS in phytobeneficial and pathogenic Proteobacteria and relation with strain biogeography. FEMS Microbiol Ecol 56, 455-470.

Boden, R., Thomas, E., Savani, P., Kelly, D. P. \& Wood, A. P. (2008). Novel methylotrophic bacteria isolated from the River Thames (London, UK). Environ Microbiol 10, 3225-3236.

Bozzola, J. J. \& Russell, L. D. (1998). Electron Microscopy, 2nd edn. Sudbury, MS: Jones \& Bartlett.

Chanprame, S., Todd, J. J. \& Widholm, J. M. (1996). Prevention of pinkpigmented methylotrophic bacteria (Methylobacterium mesophilicum) contamination of plant tissue cultures. Plant Cell Rep 16, 222-225.

Chun, J., Lee, J. H., Jung, Y., Kim, M., Kim, S., Kim, B. K. \& Lim, Y. W. (2007). EzTaxon: a web-based tool for the identification of prokaryotes based on $16 \mathrm{~S}$ ribosomal RNA gene sequences. Int J Syst Evol Microbiol 57, 2259-2261.

Dunfield, P. F., Khmelenina, V. N., Suzina, N. E., Trotsenko, Y. A. \& Dedysh, S. N. (2003). Methylocella silvestris sp. nov., a novel methanotroph isolated from an acidic forest cambisol. Int J Syst Evol Microbiol 53, 1231-1239.

Fautz, E. \& Reichenbach, H. (1980). A simple test for flexirubin-type pigments. FEMS Microbiol Lett 8, 87-91.

Felsenstein, J. (1981). Evolutionary trees from DNA sequences: a maximum likelihood approach. J Mol Evol 17, 368-376.

Felsenstein, J. (1985). Confidence limits on phylogenies: an approach using the bootstrap. Evolution 39, 783-791.

Fitch, W. M. (1971). Toward defining the course of evolution: minimum change for a specific tree topology. Syst Zool 20, 406-416.

Gerhardt, P. R., Murray, R. G. E., Wood, W. A. \& Krieg, N. R. (editors) (1994). Methods for General and Molecular Bacteriology. Washington, DC: American Society for Microbiology.

Green, P. N. \& Bousfield, I. J. (1982). A taxonomic study of some Gram-negative facultatively methylotrophic bacteria. J Gen Microbiol 128, 623-638.

Kim, B. Y., Weon, H. Y., Cousin, S., Yoo, S. H., Kwon, S. W., Go, S. J. \& Stackebrandt, E. (2006). Flavobacterium daejeonense sp. nov. and Flavobacterium suncheonense sp. nov., isolated from greenhouse soils in Korea. Int J Syst Evol Microbiol 56, 1645-1649.

Kirchman, D. L. (2002). The ecology of Cytophaga-Flavobacteria in aquatic environments. FEMS Microbiol Ecol 39, 91-100.

Kroppenstedt, R. M. (1982). Separation of bacterial menaquinones by HPLC using reverse phase (RP18) and a silver loaded ion exchanger as stationary phases. J Liq Chromatogr 5, 2359-2367. 
Lidstrom, M. E. (2006). The aerobic methylotrophic prokaryotes. In The Prokaryotes, vol. 2, pp. 618-634. Edited by M. Dworkin, K.H. Schleifer \& E. Stackebrandt. New York: Springer.

Ludwig, W., Euzéby, J. \& Whitman, W. B. (2008). Draft Taxonomic Outline of the Bacteroidetes, Planctomycetes, Chlamydiae, Spirochaetes, Fibrobacteres, Fusobacteria, Acidobacteria, Verrucomicrobia, Dictyoglomi, and Gemmatimonadetes (Bergey's Manual of Systematic Bacteriology, 2nd edn, vol. 4). http://www.bergeys.org/outlines/ Bergeys_Vol_4_Outline.pdf

Madhaiyan, M., Kim, B.-Y., Poonguzhali, S., Kwon, S.-W., Song, M.-H., Ryu, J.-H., Go, S.-J., Koo, B.-S. \& Sa, T.-M. (2007a). Methylobacterium oryzae sp. nov., an aerobic, pink-pigmented, facultatively methylotrophic, 1-aminocyclopropane-1-carboxylate deaminase-producing bacterium isolated from rice. Int J Syst Evol Microbiol 57, 326-331.

Madhaiyan, M., Poonguzhali, S. \& Sa, T. M. (2007b). Metal tolerating methylotrophic bacteria reduces nickel and cadmium toxicity and promotes plant growth of tomato (Lycopersicon esculentum L.). Chemosphere 69, 220-228.

Madhaiyan, M., Poonguzhali, S., Kwon, S. W. \& Sa, T. M. (2009). Methylobacterium phyllosphaerae sp. nov., a pink-pigmented facultatively methylotrophic bacterium from rice. Int J Syst Evol Microbiol 59, 22-27.

McDonald, I. R. \& Murrell, J. C. (1997). The methanol dehydrogenase structural gene $m x a F$ and its use as a functional gene probe for methanotrophs and methylotrophs. Appl Environ Microbiol 63, 32183224.

Mesbah, M., Premachandran, U. \& Whitman, W. B. (1989). Precise measurement of the $\mathrm{G}+\mathrm{C}$ content of deoxyribonucleic acid by highperformance liquid chromatography. Int J Syst Bacteriol 39, 159-167.

Pearson, W. R. \& Lipman, D. J. (1988). Improved tools for biological sequence comparison. Proc Natl Acad Sci U S A 85, 2444-2448.

Poonguzhali, S., Madhaiyan, M. \& Sa, T. M. (2006). Cultivationdependent characterization of rhizobacterial communities from field grown Chinese cabbage Brassica campestris ssp pekinensis and screening of potential plant growth promoting bacteria. Plant Soil 286, 167-180.

Saitou, N. \& Nei, M. (1987). The neighbor-joining method: a new method for reconstructing phylogenetic trees. Mol Biol Evol 4, 406425.

Sasser, M. (1990). Identification of bacteria through fatty acid analysis. In Methods in Phytobacteriology, pp. 199-204. Edited by Z. Klement, K. Rudolph \& D. C. Sands. Budapest: Akademiai Kiado.

Seldin, L. \& Dubnau, D. (1985). Deoxyribonucleic acid homology among Bacillus polymyxa, Bacillus macerans, Bacillus azotofixans, and other nitrogen-fixing Bacillus strains. Int J Syst Bacteriol 35, 151-154.

Stackebrandt, E., Frederiksen, W., Garrity, G. M., Grimont, P. A. D., Kämpfer, P., Maiden, M. C. J., Nesme, X., Rosselló-Mora, R., Swings, J. $\&$ other authors (2002). Report of the ad hoc committee for the reevaluation of the species definition in bacteriology. Int J Syst Evol Microbiol 52, 1043-1047.

Tamura, K., Dudley, J., Nei, M. \& Kumar, S. (2007). MEGA4: Molecular Evolutionary Genetics Analysis (MEGA) software version 4.0. Mol Biol Evol 24, 1596-1599.

Thompson, J. D., Higgins, D. G. \& Gibson, T. J. (1994). CLUSTAL W: improving the sensitivity of progressive multiple sequence alignment through sequence weighting, position-specific gap penalties and weight matrix choice. Nucleic Acids Res 22, 4673-4680.

Ueda, T., Suga, Y., Yahiro, N. \& Matsuguchi, T. (1995). Phylogeny of Sym plasmids of rhizobia by PCR-based sequencing of a nodC segment. J Bacteriol 177, 468-472.

Whittenbury, R., Davies, S. L. \& Wilkinson, J. F. (1970). Enrichment, isolation and some properties of methane-utilizing bacteria. J Gen Microbiol 61, 205-218.

Yoon, J.-H., Kang, S.-J. \& Oh, T.-K. (2006). Flavobacterium soli sp. nov., isolated from soil. Int J Syst Evol Microbiol 56, 997-1000. 